\title{
Diffuse large B cell lymphoma presenting as Horner's syndrome in a patient diagnosed with neurofibromatosis type 1: a case report and review of the literature
}

\author{
Saoraya Lueangarun ${ }^{1}$ and Chirayu U Auewarakul ${ }^{2 *}$
}

\begin{abstract}
Introduction: Horner's syndrome has a variety of etiologies ranging from benign to serious life-threatening conditions and has been infrequently reported as a presenting symptom of patients with lymphoid neoplasms. Only one case of Burkitt's lymphoma presenting with toothache, paresthesia, and Horner's syndrome has been described and no case reports of diffuse large B-cell lymphoma as the etiology of Horner's syndrome currently exist in the literature. In addition, lymphoid neoplasms have rarely been reported to occur in patients with neurofibromatosis type 1 despite an increased risk of many types of cancer in such cases.
\end{abstract}

Case presentation: A 28-year-old Thai man presented with a progressively enlarged left supraclavicular mass together with a significant weight loss and night sweating for four months. He also noticed hoarseness and ptosis of his left eye associated with double vision for two months. Physical examination revealed large supraclavicular lymphadenopathy and Horner's syndrome (ptosis, miosis, and anhydrosis) on the left side of his face. A large mediastinal mass was clearly detected by chest X-ray and computed tomography and subsequent lymph node biopsy provided a diagnosis of diffuse large B-cell lymphoma. Interestingly, the patient was also definitely diagnosed with neurofibromatosis type 1 from multiple café au lait macules, axillary freckles, three neurofibromas, multiple Lisch nodules, and a history of affected family members. He subsequently received chemotherapy with a good response. Twenty-seven cases of various types of lymphoid neoplasms previously reported to occur in neurofibromatosis type 1 patients were also extracted from the literature. All cases were non-Hodgkin lymphoma and the major subtype was T-cell. Only nine cases were B-cell lymphoma. The majority of cases were young with a median age at lymphoma diagnosis of 9.4 years (range 1.1 to 77 years). Two-thirds of the cases were boys or men. Other concomitant malignancies were brain tumor, colorectal cancer, pheochromocytoma, and acute lymphoblastic leukemia.

Conclusions: We describe for the first time a case of diffuse large B-cell lymphoma that occurred in a neurofibromatosis type 1 patient with Horner's syndrome. Horner's syndrome can be an initial manifestation of diffuse large B-cell lymphoma. Patients who present with a classical triad of Horner's syndrome should always be fully investigated for lymphomatous involvement, especially in the thorax. The exact molecular mechanism for diffuse large B-cell lymphoma development in neurofibromatosis type 1 cases remains to be elucidated.

\footnotetext{
* Correspondence: chirayuaue@yahoo.com

${ }^{2}$ Division of Hematology, Department of Medicine, Faculty of Medicine Siriraj

Hospital, Mahidol University, 2 Prannok Road, Bangkok 10700, Thailand

Full list of author information is available at the end of the article
} 


\section{Introduction}

Neurofibromatosis type 1 (NF1) (formerly known as von Recklinghausen disease) is an autosomal dominant neurocutaneous disorder characterized by several distinct clinical features such as café au lait macules, intertriginous freckling, Lisch nodules, neurofibromas, osseous dysplasia, and a family history of first-degree relatives affected by NF1 [1-3]. A variety of neoplasms have been reported to occur in association with NF1 including optic pathway gliomas, astrocytomas, brainstem gliomas, and malignant peripheral nerve sheath tumors (MPNSTs) [4-6]. Other types of tumors were also described such as pheochromocytoma, chronic myeloid leukemia, rhabdomyosarcoma, and gastrointestinal stromal tumors [1,7-9]. However, the existence of lymphoid neoplasms in patients with NF1, particularly diffuse large B-cell lymphoma (DLBCL), has been infrequently reported [1,9].

Horner's syndrome is a recognized neurological syndrome consisting of ptosis, pupillary miosis, and facial anhydrosis [10]. The syndrome occurs as a result of the interruption of the oculosympathetic pathway which could occur along its route from the hypothalamus, brain stem, spinal cord, brachial plexus, lung apex, carotid artery, cavernous sinus and finally to the eye $[10,11]$. Three types of Horner's syndrome exist according to the anatomical level of the defect, that is, central, preganglionic, and postganglionic [12]. A variety of disorders have been described in association with Horner's syndrome ranging from brain stem ischemia, brain tumors, demyelinating diseases, direct spinal cord trauma, iatrogenic disruption of the sympathetic pathway from radical neck dissection, carotid angiography, stenting or endarterectomy, spontaneous carotid dissection, aortic aneurysm to various malignant conditions that directly or indirectly affect the normal sympathetic innervations [10-12]. Primary and metastatic lung carcinoma, Pancoast tumor, thyroid carcinoma, neuroblastoma, Burkitt's lymphoma, and Hodgkin's disease have all been described as the causes of Horner's syndrome [10-13]. Interestingly, DLBCL which is the most common hematologic malignancy worldwide has never been shown to be associated with Horner's syndrome at the outset. In addition, the occurrence of DLBCL as the etiology of Horner's syndrome in an NF1 patient has not been described in the literature. We describe for the first time the case of a young Thai man with NF1 who was confirmed by pathology as having DLBCL after he presented with a classical Horner's syndrome.

\section{Case presentation}

A 28-year-old Thai man presented to Siriraj Hospital with a history of a progressively enlarged left supraclavicular mass, significant weight loss, and night sweats for four months.

Two months prior to this admission, he noticed hoarseness associated with ptosis of his left eye and double vision. The physical examination at presentation revealed ptosis of his left eye with a miotic pupil and anhydrosis on his left hemifacial area, all of which were compatible with Horner's syndrome. His skin examination disclosed several dermatologic signs such as multiple well-defined brownish café au lait patches on the abdomen, areolae, arms, back and buttocks, and axillary freckles (Figure 1). There were also soft movable skincolored nodules located on his left thigh, left forearm, and back. Subsequent ophthalmologic slit-lamp examination detected multiple Lisch nodules which are raised pigmented hamartomas of the iris. He reported having multiple pigmented skin lesions and rubbery nodular skin lesions over his entire body since childhood. His father also had similar skin lesions over the whole body area. Other pertinent examination included a large nontender and rubbery mass $(15 \mathrm{~cm}$ in length and $10 \mathrm{~cm}$ in width) in the left supraclavicular region with no palpable lymph nodes elsewhere in the body.

Routine laboratory tests revealed a hemoglobin level of $14.5 \mathrm{~g} / \mathrm{dL}$, a total leukocyte count of $8.2 \times 10^{9} / \mathrm{L}(70 \%$ neutrophils, $22 \%$ lymphocytes, and $8 \%$ monocytes) and a platelet count of $280 \times 10^{9} / \mathrm{L}$. Serum lactate dehydrogenase (LDH) was $525 \mathrm{U} / \mathrm{L}$ (normal range, 225 to 450 $\mathrm{U} / \mathrm{L}$ ) and serum uric acid was $13.4 \mathrm{mg} / \mathrm{dL}$ (normal range, 2.4 to $7 \mathrm{mg} / \mathrm{dL}$ ). His liver function tests were normal. Chest X-ray revealed a large anterior mediastinal mass (Figure 2). Computed tomography (CT) of his neck showed matted lymphadenopathy on the left side of the neck, which extended along the carotid vessels to the left thoracic cavity. Computed tomography (CT) of the chest disclosed a large $(10.9 \times 9.7 \times 18 \mathrm{~cm})$ lobulated heterogeneous-enhancing mass with a central necrosis in the anterior and middle mediastinum which extended superiorly into the left anterior neck (C5-C6 level), and encased around his aortic arch, left subclavian artery, left jugular vein, trachea, left main bronchus and left pulmonary artery (Figure 3A). Multiple subcentimeter mediastinal lymphadenopathies were also observed. Left pleural effusions with adjacent atelectasis of the left lower lobe were also present. From these findings, the differential diagnoses of this mass were lymphoma, teratoma, lung cancer or metastasis and malignancy associated with NF1, such as MPNSTs and chromaffin cells tumor. Therefore, supraclavicular lymph node biopsy was performed to make a definite pathological diagnosis which revealed diffuse, mixed small and large lymphoid cells compatible with malignant lymphoma (intermediate grade). Immunostaining 


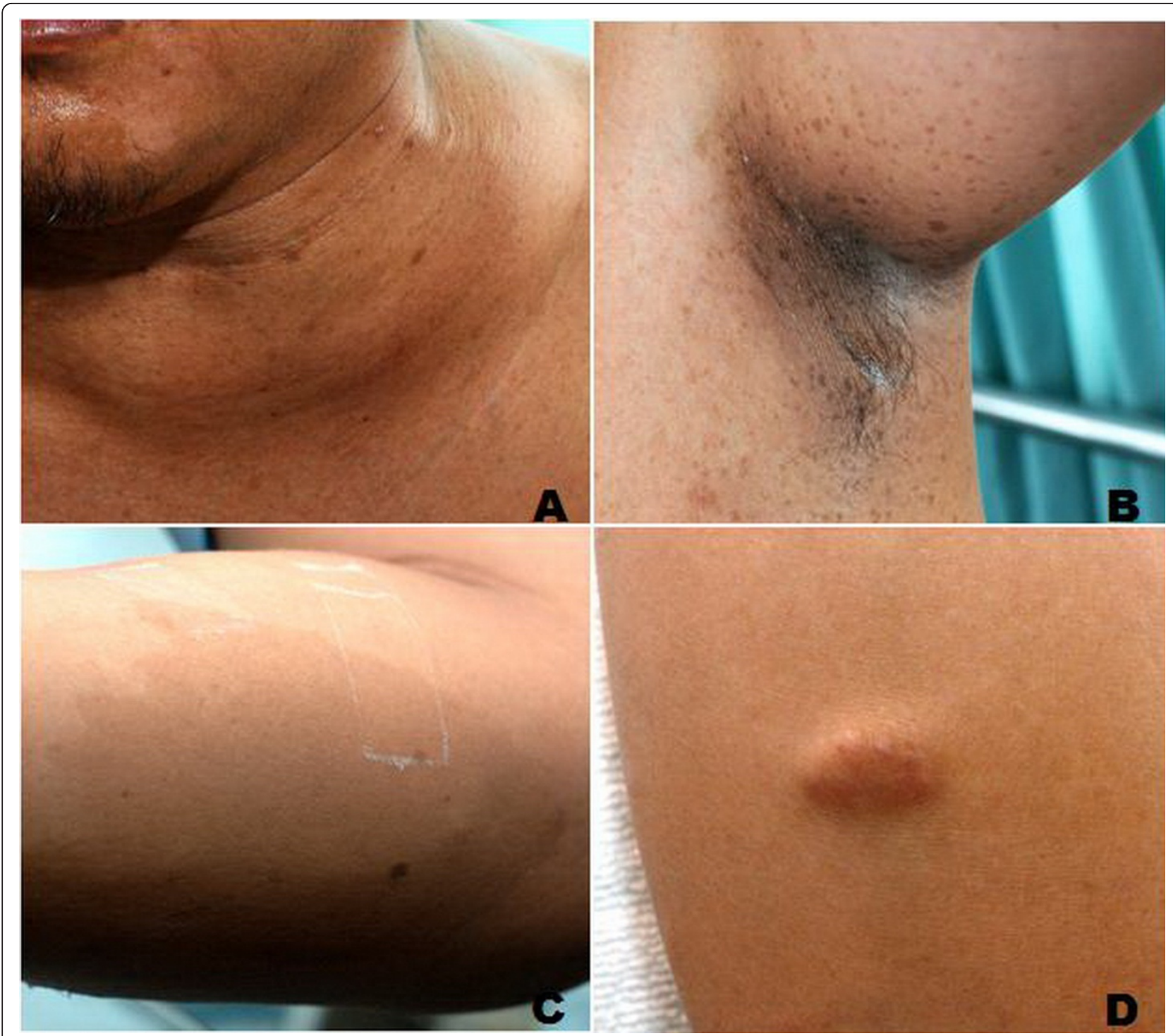

Figure 1 The patient's clinical presentations;neck mass (A), axillary freckles (B), café-au-lait macules (C), and neurofibroma (D).

of the cells demonstrated that neoplastic cells were marked with CD20, CD10, CD43, BCL2, BCL6, and MUM1, but not with CD3, CD5, CD23, CD34, TdT, or cyclin D1. Kappa but not lambda light chain restriction was also demonstrated. The malignant cells possessed a B-cell phenotype with mixed germinal center B-cell and activated B-cell features which were consistent with a DLBCL subtype according to the 2008 World Health Organization (WHO) Classification of neoplasms of the hematopoietic and lymphoid tissues [14]. Staging studies showed no bone marrow involvement and computed tomography (CT) of the whole abdomen revealed normal attenuation of liver parenchyma without a definite space occupying lesion. The spleen was unremarkable and no intraabdominal lymphadenopathy could be demonstrated. Once the diagnosis and the staging were completed, he was treated with the standard CHOP (Cyclophosphamide (Cytoxan), Hydroxyrubicin (Adriamycin), Oncovin (Vincristine), Prednisone) chemotherapy regimen for eight cycles, to which the tumor responded well (Figure $3 \mathrm{~B}$ ).

\section{Discussion}

This report describes the case of an NF1 patient who presented with a rare manifestation of malignant lymphoma, that is, Horner's syndrome. In our case, NF1 could be definitely diagnosed according to the National Institute of Health Consensus Development Conference Diagnostic Criteria which require the presence of six or more café au lait macules, two or more subcutaneous 


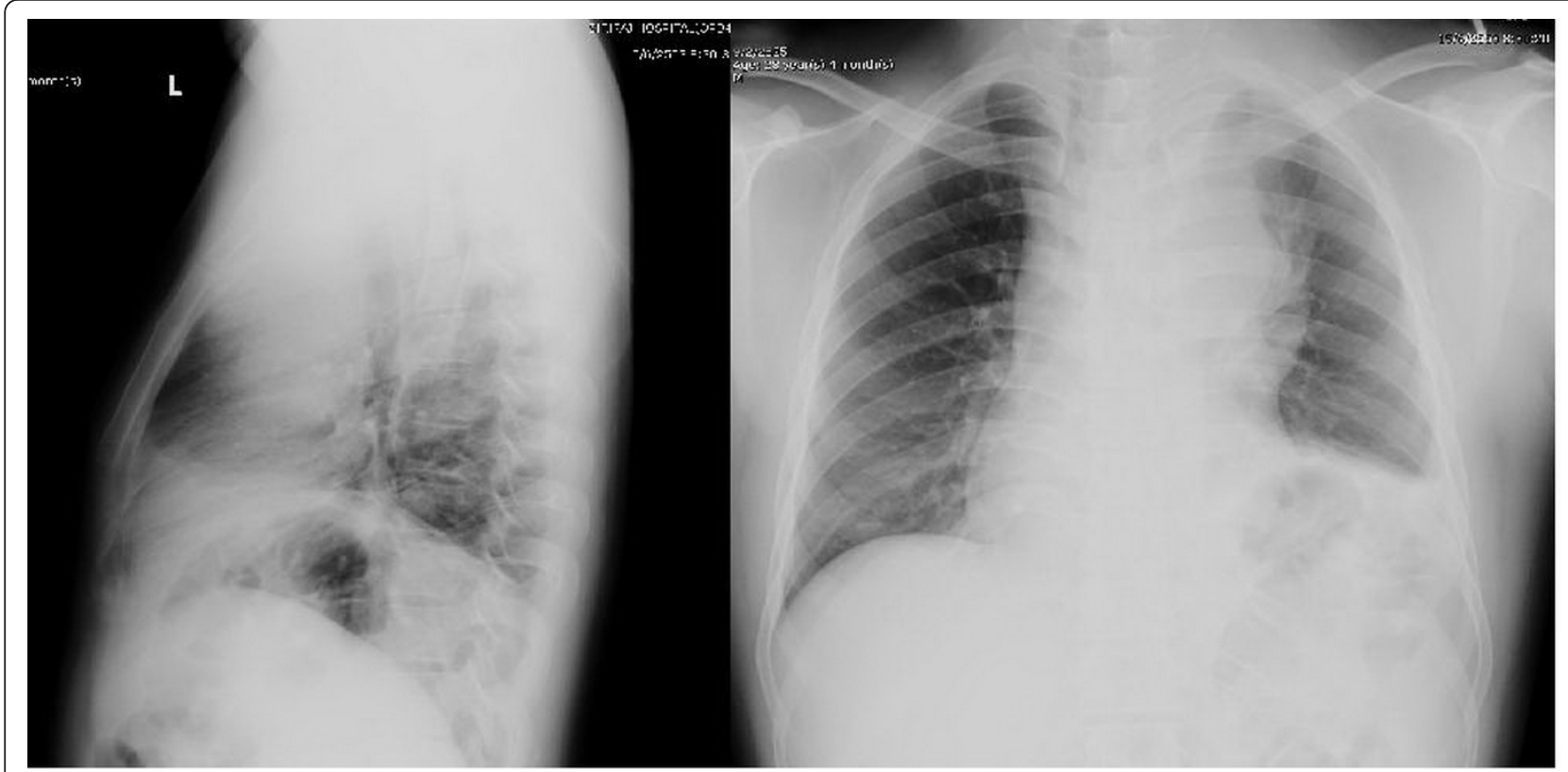

Figure 2 Chest X-ray revealed a large anterior mediastinal mass

neurofibromas, axillary or groin freckling, and two or more Lisch nodules seen on slit lamp examination [2]. An autosomal dominant family history was also demonstrated in this patient which goes along well with the typical NF1 inheritance pattern. Although it is wellknown that NF1 patients have an increased risk of malignancies with an estimated risk of $5 \%$ to $15 \%$ in affected individuals, most reported types of malignancies are not lymphoid neoplasms $[8,15]$. Since the association between NF1 and malignant lymphoma is not fully recognized, we searched the literature through the US National Library of Medicine (PUBMED) using the

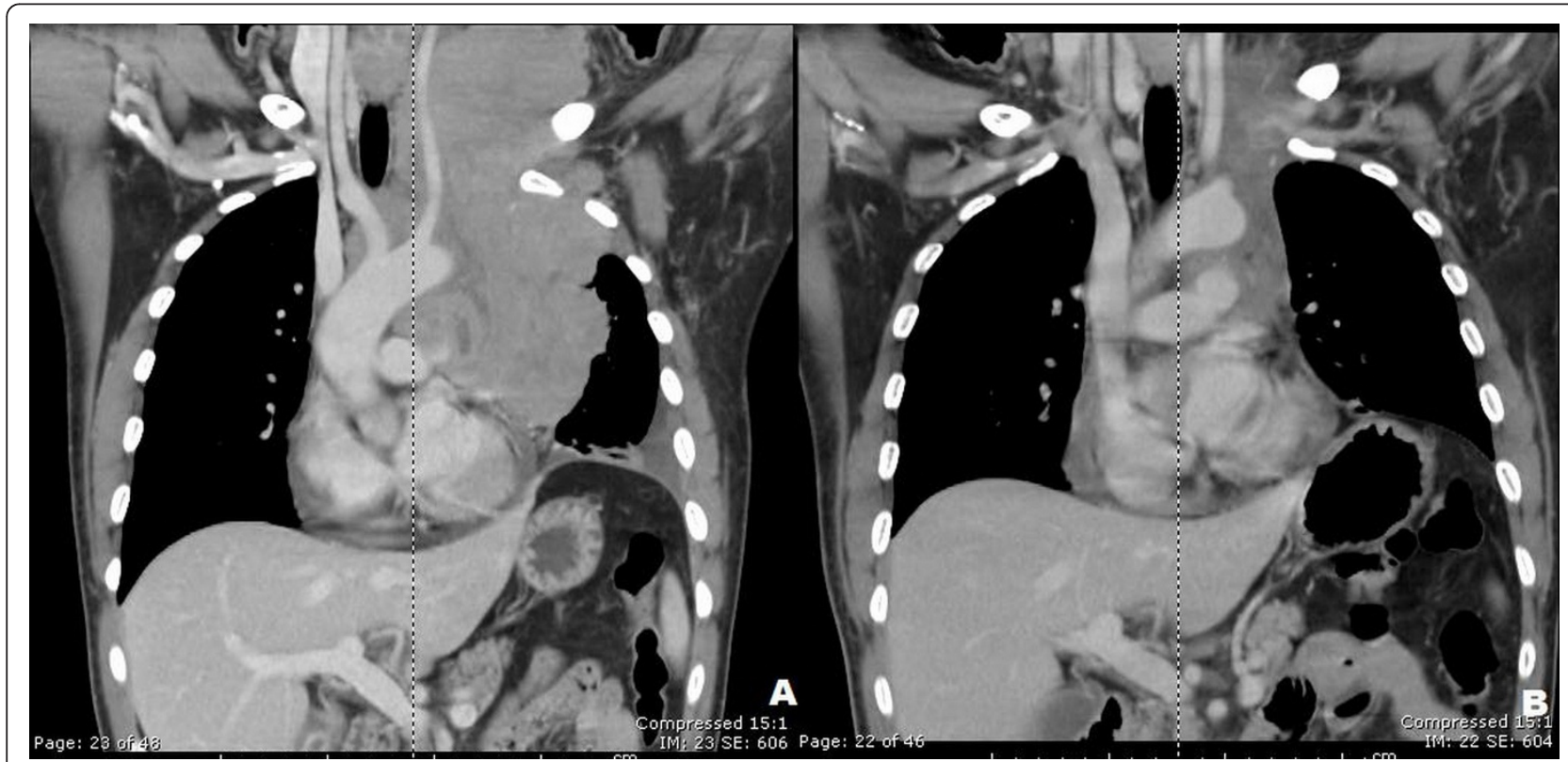

Figure 3 Computed tomography (CT) of the neck and chest showed a large lobulated heterogeneous-enhancing mass with central necrosis at the anterior and the middle mediastinum with some parts extending into the left anterior neck (A). Significant improvement of lymphomatous involvement at the prevascular region was seen after eight cycles of CHOP chemotherapy (B). CHOP, Cyclophosphamide (Cytoxan), Hydroxyrubicin (Adriamycin), Oncovin (Vincristine), Prednisone. 
keywords "malignant lymphoma", "lymphoma", and "neurofibromatosis" to find out if malignant lymphoma had been previously reported in NF1 cases and how frequently they had appeared in the literature. Only 27 cases of malignant lymphoma were reported in NF1 patients [7,16-34], and only two of them were DLBCL $[27,33]$. Table 1 summarizes details of all the reported cases except one case that was published in the nonEnglish literature [35].

With respect to the symptoms of NF1 in the reported series, 20 cases had café au lait macules (CALM), 13 cases had neurofibromas, five cases had axillary or inguinal freckles, and three cases had Lisch nodules. These cases were typical of NF1 in which CALM, neurofibroma and skin-fold freckling are the main symptoms [36]. Most of the reported cases (17 cases) had a family history of neurofibromatosis. Twelve cases had family members with neurofibromatosis and malignancies. All cases were diagnosed with non-Hodgkin's lymphoma (NHL). The majority of cases were young with a mean age of 23 years (range 1.1 to 77 years; median 9.4 years) at lymphoma diagnosis and two-thirds of the cases were boys and men. The lymphoma subtype was predominantly T-cell (13 of 25 cases), especially $\mathrm{T}$-lymphoblastic lymphoma (five cases) and cutaneous $\mathrm{T}$ cell lymphoma (two cases). Nine cases had B-cell lymphoma and five cases had unclassified lymphoma. Six cases presented with a mediastinal mass and others presented with a head and neck mass (three cases), an abdominal mass (three cases), lymphadenopathy (two cases), skin rash (two cases), a localized brain lesion (one case), and a shoulder mass (one case). No NF1 patients in prior series were reported to present with Horner's syndrome. Other concomitant malignancies identified were brain tumors (four cases), colorectal cancer (two cases), pheochromocytoma (two cases), and acute lymphoblastic leukemia (ALL) (two cases). One case developed ALL prior to NHL [21] and the remaining case developed ALL 15 months after diagnosis of NHL [7]. Additional disorders found among the 26 cases were Gardner syndrome (one case) and Gaucher's disease (one case). Thirteen cases received standard chemotherapy while six cases received radiotherapy. None of the NF1 cases received stem cell transplantation. Ten patients (37\%) responded to therapy and survived. Our patient also responded well to eight cycles of CHOP chemotherapy with resolution of his Horner's syndrome and disappearance of all tumor masses. Immunotherapy such as rituximab was not given in this particular patient due to limited availability of health insurance coverage for such costly drugs in the country.
Although the central nervous system involvement of malignant lymphoma is well documented, the interruption of the sympathetic pathway causing Horner's syndrome is an unusual manifestation of malignant lymphoma [37]. In our current review of the literature, there was only one described case of Burkitt's lymphoma presenting with toothache, paresthesia and Horner's syndrome [13,37]. Hodgkin's disease was also infrequently reported $[7,16-34]$. No cases of DLBCL as the cause of Horner's syndrome have been described in the literature. The mechanism of Horner's syndrome in this patient could be explained by the aggressive nature of DLBCL creating a huge mass in the anterior and middle mediastinum which encased his aortic arch, subclavian artery, left jugular vein, and left pulmonary artery, and extended to his left neck along the carotid vessels. The tumor mass could potentially affect the oculosympathetic pathway that normally enters the thorax, crosses the lung apex, and subsequently runs along the carotid vessels to the eyes.

The direct association between NF1 and T-cell lymphoma in most previously reported cases or between NF1 and DLBCL in this present case is unclear. The NF1 gene is a tumor suppressor gene and multiple key pathways are potentially involved in the development of cancer in NF1 cases such as RAS/mitogen-activated protein kinase (MAPK) and AKT/mammalian target of rapamycin (mTOR) [38,39]. Germline mutations of the NF1 generally result in decreased intracellular neurofibromin protein levels and lead to increased RAS signaling to its downstream effectors [38]. Mutations in the DNA mismatch repair genes, such as MLH1 (human mutL homolog 1) [24,25] and MSH6 (human mutS homolog 6), have been reported in NF1 cases with malignant lymphoma (as shown in Table 1), early-onset CNS tumors, and colorectal cancer [31]. Lymphoma potentially occurs in NF1 patients through a series of proto-oncogene activation and mismatch repair gene mutations although the precise pathogenetic mechanism needs to be further explored.

\section{Conclusion}

DLBCL has never been shown to manifest initially as Horner's syndrome. To the best of our knowledge, our case represents the first case ever of Horner's syndrome that occurred as a result of oculosympathetic interruption by DLBCL. This case reveals a rare association between NF1 and DLBCL in contrast to other more common non-hematologic malignancies that frequently occurred in NF1 cases. Molecular mechanisms required for the initiation and propagation of lymphoma in NF1 cases should be determined to answer why and how 
Table 1 Summarized data of all reported NF1 cases with lymphoma development

\begin{tabular}{|c|c|c|c|c|c|c|c|c|c|c|}
\hline $\begin{array}{l}\text { Case } \\
\text { No. }\end{array}$ & References & $\begin{array}{l}\text { Sex/ } \\
\text { Age at } \\
\text { onset } \\
\text { (y) }\end{array}$ & Lymphoma & Other tumor(s) & $\begin{array}{l}\text { Presentation of } \\
\text { lymphoma }\end{array}$ & $\begin{array}{l}\text { Family } \\
\text { history } \\
\text { of } \\
\text { NF1 }\end{array}$ & $\begin{array}{l}\text { Family } \\
\text { history } \\
\text { of } \\
\text { cancer }\end{array}$ & NF criteria* & Treatment & Outcome \\
\hline 1. & {$[16]$} & $F, 20$ & Burkitt lymphoma & Pheochromocytoma & $\begin{array}{l}\text { dental extract site } \\
\text { mass }\end{array}$ & NA & NA & CALM, neurofibromas & $\begin{array}{l}\text { Chemotherapy } \\
\text { and } \\
\text { radiotherapy }\end{array}$ & Alive \\
\hline 2. & {$[17]$} & M, 11 & $\begin{array}{l}\text { Diffuse, poorly } \\
\text { differentiated } \\
\text { lymphoma }\end{array}$ & Glioblastoma multiforme & $\begin{array}{l}\text { anterior mediastinal } \\
\text { mass }\end{array}$ & Y & Y & CALM & Chemotherapy & Death \\
\hline 3. & [18] & $F, 6$ & $\begin{array}{l}\text { T-cell lymphoblastic } \\
\text { lymphoma }\end{array}$ & Gardner syndrome & $\begin{array}{l}\text { mediastinal mass } \\
\text { and pleural effusion }\end{array}$ & Y & Y & CALM & $\begin{array}{l}\text { Chemotherapy } \\
\text { and } \\
\text { radiotherapy }\end{array}$ & Death \\
\hline 4. & {$[18]$} & $F, 1.1$ & $\begin{array}{l}\text { T-cell lymphoblastic } \\
\text { lymphoma }\end{array}$ & & neck mass & Y & Y & CALM & Radiotherapy & Death \\
\hline 5. & {$[18]$} & $M, 4$ & $\begin{array}{l}\text { T-cell lymphoblastic } \\
\text { lymphoma }\end{array}$ & & $\begin{array}{l}\text { mediastinal mass } \\
\text { and pleural effusion }\end{array}$ & Y & Y & CALM, neurofibromas & $\begin{array}{l}\text { Chemotherapy } \\
\text { and } \\
\text { radiotherapy }\end{array}$ & Death \\
\hline 6. & {$[7]$} & M, 16 & T-cell lymphoma & $\begin{array}{l}\text { Acute lymphoblastic leukemia, } 15 \\
\text { months after diagnosis of } \\
\text { lymphoma }\end{array}$ & mediastinal mass & Y & Y & CALM & $\begin{array}{l}\text { Chemotherapy } \\
\text { and } \\
\text { radiotherapy }\end{array}$ & Death \\
\hline 7. & {$[19]$} & $M, 45$ & $\begin{array}{l}\text { Well-differentiated } \\
\text { lymphocytic lymphoma }\end{array}$ & $\begin{array}{l}\text { Pheochromocytoma, renal artery } \\
\text { stenosis }\end{array}$ & abdominal mass & NA & NA & CALM, neurofibromas & NA & Alive \\
\hline 8. & {$[20]$} & $M, 59$ & $\begin{array}{l}\text { Diffuse, medium sized } \\
\text { cell type, B cell type } \\
\text { NHL }\end{array}$ & & lymphadenopathy & Y & NA & CALM, neurofibromas & Chemotherapy & Death \\
\hline 9. & {$[21]$} & $M, 7.8$ & $\mathrm{~T}-\mathrm{NHL}$ & $\begin{array}{l}\text { Acute lymphoblastic leukemia, } \\
\text { prior to NHL }\end{array}$ & & $Y$ & Y & NA & NA & Death \\
\hline 10. & {$[21]$} & $F, 4.1$ & T-NHL & & & Y & Y & NA & NA & Death \\
\hline 11. & {$[21]$} & $M, 1.6$ & $\mathrm{~T}-\mathrm{NHL}$ & & & Y & Y & NA & NA & Death \\
\hline 12. & {$[21]$} & M, 13.7 & $\begin{array}{l}\text { Mixed } \\
\text { centroblastic/ } \\
\text { centrocytic NHL }\end{array}$ & & & Y & NA & NA & NA & Alive \\
\hline 13. & {$[21]$} & $M, 7.2$ & $\mathrm{~B}-\mathrm{NHL}$ & & & $\mathrm{N}$ & NA & NA & NA & Death \\
\hline 14. & {$[22]$} & $F, 4.6$ & B-cell NHL & Glioblastoma multiforme & right iliac fossa mass & $\mathrm{N}$ & $\mathrm{N}$ & CALM, neurofibromas & Chemotherapy & Alive \\
\hline 15. & {$[23]$} & $M, 65$ & $\begin{array}{l}\text { Diffuse mixed type, } \mathrm{T} \\
\text { cell type } \mathrm{NHL}\end{array}$ & & $\begin{array}{l}\text { generalized } \\
\text { lymphadenopathy }\end{array}$ & Y & NA & CALM, neurofibromas & Chemotherapy & Death \\
\hline 16. & {$[24]$} & $F, 2^{* *}$ & Undifferentiated NHL & & & Y & Y & $\begin{array}{l}\text { CALM, neurofibromas, } \\
\text { pseudoarthrosis }\end{array}$ & NA & Death \\
\hline 17. & [25] & $M, 3.3^{* *}$ & $\mathrm{NHL}$ & & & Y & Y & CALM & NA & Death \\
\hline
\end{tabular}


Table 1 Summarized data of all reported NF1 cases with lymphoma development (Continued)

\begin{tabular}{|c|c|c|c|c|c|c|c|c|c|c|}
\hline 18. & {$[26]$} & $M, 44$ & $\begin{array}{l}\text { Cutaneous T-cell } \\
\text { lymphoma }\end{array}$ & Astrocytoma & skin rash & NA & NA & $\begin{array}{l}\text { CALM, neurofibromas, } \\
\text { freckles }\end{array}$ & $\begin{array}{l}\text { Phototherapy } \\
\text { and topical } \\
\text { steroid }\end{array}$ & Alive \\
\hline 19. & {$[27]$} & $F, 77$ & DLBCL & & $\begin{array}{l}\text { left lower abdominal } \\
\text { mass and weight } \\
\text { loss }\end{array}$ & Y & NA & CALM, neurofibromas & Chemotherapy & Alive \\
\hline 20. & {$[28]$} & $M, 2$ & T-cell NHL & Colorectal cancer & $\begin{array}{l}\text { testicular and } \\
\text { mediastinal mass }\end{array}$ & Y & NA & CALM, freckle & $\begin{array}{l}\text { Chemotherapy } \\
\text { and } \\
\text { radiotherapy }\end{array}$ & Alive \\
\hline 21. & {$[29]$} & $M, 72$ & $\begin{array}{l}\text { Cutaneous T-cell } \\
\text { lymphoma }\end{array}$ & & skin rash & Y & NA & $\begin{array}{l}\text { CALM, neurofibromas, } \\
\text { freckles, Lisch } \\
\text { nodules }\end{array}$ & NA & Alive \\
\hline 22. & {$[30]$} & $M, 47$ & $\begin{array}{l}\text { CNS lymphoma, B cell } \\
\text { type }\end{array}$ & & $\begin{array}{l}\text { parieto-occipital lobe } \\
\text { mass }\end{array}$ & NA & NA & $\begin{array}{l}\text { Neurofibromas, Lisch } \\
\text { nodules }\end{array}$ & NA & NA \\
\hline 23. & {$[31]$} & $M, 9.4$ & T-cell lymphoma & Anaplastic astrocytoma & mediastinal mass & $\mathrm{N}$ & Y & CALM, freckles & Chemotherapy & Death \\
\hline 24. & {$[32]$} & $M, 5^{* * *}$ & $\begin{array}{l}\text { Lymphoblastic } \\
\text { lymphoma }\end{array}$ & Colorectal cancer & & Y & Y & CALM, freckles & NA & Death \\
\hline 25. & {$[33]$} & $\mathrm{F}, 50$ & DLBCL & & shoulder mass & $\mathrm{N}$ & $\mathrm{N}$ & CALM, neurofibromas & Chemotherapy & Alive \\
\hline 26. & {$[34]$} & $F, 6$ & $\begin{array}{l}\text { Mediastinal T-cell } \\
\text { lymphoblastic } \\
\text { lymphoma }\end{array}$ & Gaucher's disease & & NA & NA & NA & NA & NA \\
\hline 27. & $\begin{array}{l}\text { Present } \\
\text { case }\end{array}$ & M, 28 & DLBCL & & neck mass & $N$ & $N$ & $\begin{array}{l}\text { CALM, neurofibromas, } \\
\text { freckles, Lisch } \\
\text { nodules }\end{array}$ & Chemotherapy & Alive \\
\hline
\end{tabular}

Abbreviations: CALM, café au lait macules; CNS, central nervous system; DLBCL, diffuse large B-cell lymphoma; $F$, female; $M$, male; N, No; NA, not available; NF, neurofibromatosis; NF1, neurofibromatosis type 1; NHL, non-Hodgkin's lymphoma; $y$, years; $Y$, Yes;

*Freckles include axillary or inguinal freckles

** Presence of MLH1 (human mutL homolog 1) mutation

***Presence of MSH6 (human mutS homolog 6) mutation 
only a very few NF1 cases are at risk of lymphoma development in their lifetimes.

\section{Consent}

Written informed consent was obtained from the patient for publication of this case report and any accompanying images. A copy of the written consent is available for review by the Editor-in-Chief of this journal.

\section{Acknowledgements}

The authors wish to thank Dr. Sanya Sukpanichnant and Dr. Komgrid Charngkaew from the Department of Pathology, Faculty of Medicine Siriraj Hospital for performing the pathological diagnosis of the lymph node biopsy, and Dr. Pipat Chiewvit from the Department of Radiology, Faculty of Medicine Siriraj Hospital for radiologic interpretation. Finally, the authors would like to thank Dr. Therdpong Tempark and Dr. Paworn Nuntakij for their assistance with manuscript preparation. CUA was supported by the Chalermprakiate Fund, Faculty of Medicine Siriraj Hospital, Mahidol University.

\section{Author details}

'Department of Medicine, Faculty of Medicine Siriraj Hospital, Mahidol University, 2 Prannok Road, Bangkok 10700, Thailand. ${ }^{2}$ Division of Hematology, Department of Medicine, Faculty of Medicine Siriraj Hospital, Mahidol University, 2 Prannok Road, Bangkok 10700, Thailand.

\section{Authors' contributions}

SL performed data collection and analysis and drafting of the manuscript. CUA was SL's major advisor who was responsible for the critical revision of the manuscript. Both authors read and approved the final manuscript.

\section{Competing interests}

The authors declare that they have no competing interests.

Received: 26 August 2011 Accepted: 11 January 2012 Published: 11 January 2012

\section{References}

1. Jett K, Friedman JM: Clinical and genetic aspects of neurofibromatosis 1. Genet Med 2010, 12:1-11.

2. Neurofibromatosis. Conference statement. National Institutes of Health Consensus Development Conference. Arch Neurol 1988, 45:575-578.

3. Huson SM, Acosta MT, Belzberg AJ, Bernards A, Chernoff J, Cichowski K, Gareth Evans D, Ferner RE, Giovannini M, Korf BR, Listernick R, North KN, Packer RJ, Parada LF, Peltonen J, Ramesh V, Reilly KM, Risner JW, Schorry EK, Upadhyaya M, Viskochil DH, Zhu Y, Hunter-Schaedle K, Giancotti FG: Back to the future: proceedings from the $2010 \mathrm{NF}$ Conference. Am J Med Genet A 2011, 155A:307-321.

4. Ferner RE, Gutmann DH: International consensus statement on malignant peripheral nerve sheath tumors in neurofibromatosis. Cancer Res 2002, 62:1573-1577.

5. Guillamo JS, Creange A, Kalifa C, Grill J, Rodriguez D, Doz F, Barbarot S, Zerah M, Sanson M, Bastuji-Garin S, Wolkenstein P: Prognostic factors of CNS tumours in Neurofibromatosis 1 (NF1): a retrospective study of 104 patients. Brain 2003, 126:152-160.

6. Verma R, Chhabra A, Bhutani C, Jain D, Singh J: Neurofibromatosis: a diagnostic mimicker on $\mathrm{CT}$ in a known case of malignancy. Indian J Cancer 2002, 39:151-153.

7. Wertelecki W, linuma K, Bentley HP: Non-neural malignancy complicating neurofibromatosis in two relatives. Cancer Genet Cytogenet 1985, 18:87-89.

8. Sorensen SA, Mulvihill JJ, Nielsen A: Long-term follow-up of von Recklinghausen neurofibromatosis. Survival and malignant neoplasms. N Engl J Med 1986, 314:1010-1015.

9. Korf BR: Malignancy in neurofibromatosis type 1. Oncologist 2000, 5:477-485.

10. Walton KA, Buono LM: Horner syndrome. Curr Opin Ophthalmol 2003, 14:357-363.
11. Reede DL, Garcon E, Smoker WR, Kardon R: Horner's syndrome: clinical and radiographic evaluation. Neuroimaging Clin N Am 2008, 18:369-385, xi.

12. Lee JH, Lee HK, Lee DH, Choi CG, Kim SJ, Suh DC: Neuroimaging strategies for three types of Horner syndrome with emphasis on anatomic location. AJR Am J Roentgenol 2007, 188:W74-81.

13. Nissenbaum M, Kaban LB, Troulis MJ: Toothache, paresthesia, and Horner syndrome: an unusual presentation of disseminated Burkitt's lymphoma. J Oral Maxillofac Surg 2007, 65:1395-1401.

14. Swerdlow SH, Campo E, Harris NL: WHO Classification of Tumours of Haematopoietic and Lymphoid Tissues Lyon: IARC Press; 2008.

15. Walker L, Thompson D, Easton D, Ponder B, Ponder M, Frayling I, Baralle D: A prospective study of neurofibromatosis type 1 cancer incidence in the UK. Br J Cancer 2006, 95:233-238.

16. Berman BW, Binder RA, Cornfield DB: Burkett lymphoma in a patient with neurofibromatosis and pheochromocytoma. JAMA 1977, 237:993-994.

17. Li F, Mclntosh S, Peng-Whang J: Double primary cancers in 2 young sibs, leukemia in another, and dextrocardia in a fourth. Cancer 1977, 39:2633-2636.

18. Kaplan J, Cushing B, Chang CH, Poland R, Roscamp J, Perrin E, Bhaya N: Familial T-cell lymphoblastic lymphoma: association with Von Recklinghausen neurofibromatosis and Gardner syndrome. Am J Hematol 1982, 12(3):247-50

19. Kremen AF, Hill E, Kremen AJ: Pheochromocytoma, renal artery stenosis, and lymphocytic lymphoma associated with von Recklinghausen's neurofibromatosis. Case report and literature review. Minn Med 1985, 68(2):99-101.

20. Matsuzaki M, Shimamoto Y, Yokoyama Y, Suga K, Tokioka T, Sueoka E, Ono K, Sano M, Yamaguchi M: [von Recklinghausen's disease associated with malignant lymphoma]. Rinsho Ketsueki 1989, 30:382-386.

21. Stiller CA, Chessells JM, Fitchett M: Neurofibromatosis and childhood leukaemia/lymphoma: a population-based UKCCSG study. $\mathrm{Br} J$ Cancer 1994, 70:969-972.

22. Uyttebroeck A, Legius E, Brock P, Van de Cassey W, Casaer P, Casteels-Van Daele M: Consecutive glioblastoma and B cell non-Hodgkin's lymphoma in a young child with von Recklinghausen's Neurofibromatosis. Med Pediatr Oncol 1995, 24:46-49.

23. Itoh T, Tamegane T, Ohmae Y, Nakayama S: [Malignant lymphoma occurring in a patient with neurofibromatosis type 1 (von Recklinghausen disease)]. Rinsho Ketsueki 1998, 39:698-702.

24. Wang Q, Lasset C, Desseigne F, Frappaz D, Bergeron C, Navarro C, Ruano E, Puisieux A: Neurofibromatosis and early onset of cancers in hMLH1deficient children. Cancer Res 1999, 59:294-297.

25. Ricciardone MD, Ozcelik T, Cevher B, Ozdag H, Tuncer M, Gurgey A, Uzunalimoglu O, Cetinkaya H, Tanyeli A, Erken E, Ozturk M: Human MLH1 deficiency predisposes to hematological malignancy and neurofibromatosis type 1. Cancer Res 1999, 59:290-293.

26. Braam P, Sanders CJ, Canninga-Van Dijk MR: Neurofibromatosis type 1 and mycosis fungoides. Int J Dermatol 2002, 41:236-238.

27. Kim SJ, Seo JH, Lee SW, Han E, Lee ES, Cha SH, Seo BK: A case of nonHodgkin's lymphoma in a patient with neurofibromatosis type 1. Korean J Intern Med 2003, 18:202-205.

28. Barbaric D, Stevens M, Dalla-Pozza L: Neurofibromatosis type 1 and multiple primary malignancies. Med Pediatr Oncol 2003, 41:568-569.

29. Herbert CR, McBurney El: Cutaneous T-cell lymphoma in a patient with neurofibromatosis type 1. Cutis 2003, 72:27-30.

30. Zein G, Yu E, Tawansy K, Berta A, Foster CS: Neurofibromatosis type 1 associated with central nervous system lymphoma. Ophthalmic Genet 2004, 25:49-51.

31. Ostergaard JR, Sunde L, Okkels H: Neurofibromatosis von Recklinghausen type I phenotype and early onset of cancers in siblings compound heterozygous for mutations in MSH6. Am J Med Genet A 2005, 139A:96-105, discussion 196.

32. Hegde MR, Chong B, Blazo ME, Chin LH, Ward PA, Chintagumpala MM, Kim JY, Plon SE, Richards CS: A homozygous mutation in MSH6 causes Turcot syndrome. Clin Cancer Res 2005, 11:4689-4693.

33. Dohi O, Hatori M, Ichinohasama R, Hosaka M, Hashimoto S, Kokubun S: Diffuse large $B$-cell lymphoma arising in a patient with neurofibromatosis type I and in a patient with neurofibromatosis type II. Tohoku J Exp Med 2006, 208:169-176.

34. Cajaiba MM, Reyes-Mugica M: Gaucher or pseudo-Gaucher? The challenge of several diseases colliding in a pediatric patient. Hum Pathol 2009, 40:594-598. 
35. Tamaro P, Bouquet F, Zanazzo GA, Zippo GF: [Recklinghausen's disease and malignant hemopathies]. Riv Neurobiol 1982, 28:463-467.

36. Ferner RE: Neurofibromatosis 1 and neurofibromatosis 2: a twenty first century perspective. Lancet Neurol 2007, 6:340-351.

37. Maloney W, Younge B, Moyer N: Evaluation of the causes and accuracy of pharmacologic localization in Horner's syndrome. Am J Ophthalmol 1980, 90:394-402.

38. Gottfried ON, Viskochil DH, Couldwell WT: Neurofibromatosis Type 1 and tumorigenesis: molecular mechanisms and therapeutic implications. Neurosurg Focus 2010, 28:E8.

39. Parkin B, Ouillette P, Wang Y, Liu Y, Wright W, Roulston D, Purkayastha A, Dressel A, Karp J, Bockenstedt P, Al-Zoubi A, Talpaz M, Kujawski L, Liu Y, Shedden K, Shakhan S, Li C, Erba H, Malek SN: NF1 inactivation in adult acute myelogenous leukemia. Clin Cancer Res 2010, 16:4135-4147.

doi:10.1186/1752-1947-6-8

Cite this article as: Lueangarun and Auewarakul: Diffuse large B cell lymphoma presenting as Horner's syndrome in a patient diagnosed with neurofibromatosis type 1: a case report and review of the literature. Journal of Medical Case Reports 2012 6:8.

\section{Submit your next manuscript to BioMed Central} and take full advantage of:

- Convenient online submission

- Thorough peer review

- No space constraints or color figure charges

- Immediate publication on acceptance

- Inclusion in PubMed, CAS, Scopus and Google Scholar

- Research which is freely available for redistribution

Submit your manuscript at www.biomedcentral.com/submit 